\title{
Implementasi Pengelolaan dan Pemantauan Lingkungan Hidup Sekitar Kegiatan Kehutanan
}

\author{
M. Fikri Hernandi \\ Forest Products \\ Technology Department, \\ Samarinda State of \\ Agriculture Polytechnic \\ fhernandi271170@gmail \\ .com
}

\author{
Erna Rositah \\ Forest Management \\ Department, \\ Samarinda State of \\ Agriculture Polytechnic \\ Ernarositah7@gmail.com
}

\author{
Wartomo \\ Forest Products \\ Technology Department, \\ Samarinda State of \\ Agriculture Polytechnic \\ wartomopoltanesa@gmail \\ .com
}

\author{
Abdul Rasyid Zarta \\ Wood Engineering \\ Department, \\ Samarinda State of \\ Agriculture Polytechnic \\ zarta_poltanesa@yahoo.com \\ *Corresponding author
}

\begin{abstract}
Abstrak - Kualitas pelaporan belum sepenuhnya memenuhi Pedoman Kepmen LH Nomor 45/2005 terutama format laporan dan subtansi pelaporan.

Realisasi jenis dampak yang wajib dikelola dan dipantau kategori "baik". Tingkat capaian implementasi kegiatan pengelolaan dan pemantauan dampak lingkungan pada kategori "cukup baik"

Implementasi pengelolaan dan pemantauan lingkungan belum optimal disebabkan oleh permasalahan koordinasi dan komitmen perusahaan, fokus kebijakan sektoral (PHPL dan Proper), jadwal dan kapasitas laboratorium, kapasitas pengetahuan dan kompetensi staf serta tidak ada umpan balik/koreksi. Penilaian pelaksanaan RKL-RPL oleh Instansi Lingkungan Hidup belum optimal disebabkan oleh permasalahan jumlah, kapasitas pengetahuan dan kompetensi staff.

Evaluasi terhadap beberapa dampak hasil pemantauan masih memenuhi ketentuan/standar ilmiah. laju erosi kategori "Kelas III" atau "TBE sedang". Kualitas air sungai sebesar 93,33\% kategori "memenuhi BML" dan 6,67\% kategori "telah melampaui BML". Parameter air pada tingkat kritis "rendah" (68,89\%). Indeks Pencemaran (IP) 66,67\% tercemar "ringan" (IP 2,11-3,23) dan 33,33\% kondisi "baik" (IP 0,29-0,84). Parameter air sungai yang tidak memenuhi BML meliputi timbal, $\mathrm{DO}, \mathrm{CaCO}_{3}$, nitrit. Indeks keanekaragaman Shannon-Wiener vegetasi termasuk kriteria "tinggi". Indeks keanekaragaman Shannon-Wiener fauna termasuk kriteria "sedang". Indeks keanekaragaman Shannon-Wiener untuk plankton termasuk kriteria stabilitas komunitas biota sedang atau kualitas air tercemar sedang, sebaliknya untuk bentos termasuk kriteria stabilitas komunitas biota rendah atau kualitas air tercemar berat. Rekruitmen tenaga kerja lokal sebesar $90 \%$ atau meningkat $29,57 \%$ dari sebelum operasional.
\end{abstract}

Kata Kunci-implementasi pengelolaan dan pemantauan, dampak lingkungan, kehutanan, kategori lingkungan

\section{PENDAHULUAN}

Kalimantan Timur memiliki aset kekayaan sumberdaya alam yang melimpah dan berskala besar, khususnya sumberdaya hutan tropis. Pemanfaatan dan pengembangan SDA pada kawasan peruntukan kehutanan seluas 6.055.793 ha (Perda Kaltim No. 1/2016). Realisasi pemanfaatan SDA hingga tahun 2019 pada kawasan kehutanan dikelola 60 perusahaan seluas 3.924.570 ha hutan alam dan dikelola 44 perusahaan seluas 1.620 .813 ha hutan tanaman.

Konsekuensi logis dari eksploitasi SDA adalah munculnya dampak terhadap lingkungan baik lingkungan fisik, biologi maupun sosial. Penurunan lingkungan hidup telah tergambarkan berupa pencemaran badan air dan udara, kontaminasi limbah bahan berbahaya dan beracun (B3), kerusakan ekosistem hutan hujan tropika, pemanasan bumi serta bencana lingkungan seperti banjir dan longsor, kekeringan, kebakaran hutan dan lahan yang cenderung terus meningkat. Hal ini diperkuat dalam laporan Dinas Lingkungan Hidup Provinsi Kalimantan Timur Januari 2019 mengemukakan beberapa isu lingkungan hidup dari aspek fisik yakni pencemaran air, udara dan tanah; pemanfaatan dan pengelolaan sumderdaya alam yang kurang menerapkan prinsip ramah lingkungan dan berkelanjutan; degradasi hutan; belum optimalnya implementasi rencana kelola dan perlindungan lingkungan atau keanekaragaman hayati.

Bidang kehutanan, perkebunan dan pertanian berkontribusi $68 \%$ emisi total yang dihasilkan melalui deforestasi, perusakan hutan, pembakaran dan pengeringan lahan gambut kaya karbon (Dewan Daerah Perubahan Iklim Kalimantan Timur, 2010). Menurut Forest Watch Indonesia (2017), kurun waktu 2013-2016 perubahan tutupan hutan di Provinsi Kalimantan Timur seluas \pm 472 ribu hektare. Selanjutnya data Kementerian Lingkungan Hidup dan Kehutanan (2019), angka deforestasi di dalam dan di luar kawasan hutan periode tahun 2017-2018 di Provinsi Kalimantan Timur mencapai 44.709,9 ha.

Untuk mengendalikan kerusakan lingkungan hidup diperlukan kontrol yang kuat dari seluruh parapihak (perusahaan, pemerintah dan seluruh masyarakat). 
Mengingat besarnya potensi negatif, tanggung jawab perusahaan dalam rangka perlindungan dan pengelolaan lingkungan hidup (PPLH) dengan melakukan pencegahan pencemaran dan/atau kerusakan lingkungan hidup melalui instrumen pencegahan berupa kewajiban menyusun kajian lingkungan Analisis Mengenai Dampak Lingkungan (AMDAL) dan perizinan sesuai UU 32/2009 Pasal 22 Ayat 1.

Tahap implementasi pengelolaan dan pemantauan dampak lingkungan sebagaimana tercantum dalam dokumen RKL-RPL merupakan bentuk tanggung jawab perusahaan secara konsisten melaksanakan izin lingkungan dalam rangka PPLH. Dalam diktum keputusan kelayakan dan izin lingkungan dinyatakan penanggung jawab usaha dan/atau kegiatan dalam melaksanakan kegiatannya wajib melakukan pengelolaan dan pemantauan dampak lingkungan hidup sebagaimana tercantum dalam dokumen RKL-RPL yang telah disetujui. Selanjutnya penanggung jawab usaha dan/atau kegiatan berkewajiban membuat dan menyampaikan laporan pelaksanaan sesuai Pasal 68 UU 32/2009 dan Pasal 53 PP 27/2012 Disisi pemerintah memiliki peran dan kewenangan sebagai pengawasan sebagaimana Pasal 72 dan Pasal 63 ayat 1 huruf o dalam UU 32/2009. Penelitian ini bertujuan untuk mereview dan menganalisis implementasi pengelolaan dan pemantauan dampak lingkungan pada kegiatan kehutanan sebagai upaya perlindungan dan pengelolaan lingkungan hidup.

\section{Metodologi}

A. Lokasi dan data penelitian

Wilayah kegiatan Izin Usaha Pemanfaatan Hasil Hutan Kayu pada Hutan Alam (IUPHHK-HA) PT XYX di Kabupaten Kutai Timur Provinsi Kalimantan Timur.

\section{B. Analisis Data}

Teknik analisis data yang digunakan adalah analisis deskriptif kualitatif-kuantitatif. Penyajian data yang telah terkumpulkan ditabulasi untuk selanjutnya diolah (dipilah, dikelompokkan, dan diklasifikasi) berdasarkan tujuan analisis sebagai berikut:

a. Tingkat pencapaian hasil implementasi pengelolaan dan pemantauan dampak lingkungan, meliputi :

- Kualitas dan kelengkapan dokumen pelaporan berdasarkan Kepmen LHK Nomor: 45 Tahun 2005 dengan indikator penilaian : Kelengkapan dokumen perizinan; Penyampaian laporan; Frekuensi pelaporan; Substansi dokumen

- Kesesuaian rumusan Rencana Pengelolaan Lingkungan Hidup (RKL) dengan capaian hasil implementasi pengelolaan dengan indikator : jenis dampak; bentuk atau tindakan; lokasi.

- Kesesuaian rumusan Rencana Pemantauan Lingkungan Hidup (RPL) dengan capaian hasil implementasi pemantauan dengan indikator : jenis dampak; parameter; lokasi

- Penilaian capaian hasil implementasi melalui pembobotan : N $=\frac{\sum \text { IPL }}{\sum \text { RPL }}$ X $100 \%$, keterangan : $\sum \mathrm{IP}=$ Jumlah hasil implementasi; $\sum \mathrm{RP}=$ Jumlah rencana

Selanjutnya kategori nilai kesesuaian rencana dan hasil implementasi pengelolaan dan pemantauan diklasifikasikan seperti pada tabel 1 berikut.

Tabel 1. Kategori Penilaian Tingkat Capaian Hasil Implementasi Pengelolaan dan Pemantauan Dampak Lingkungan Hidup

\begin{tabular}{|c|c|}
\hline Kategori & Keterangan \\
\hline $\begin{array}{c}\text { Baik } \\
(100 \%)\end{array}$ & $\begin{array}{l}\text { Melaksanakan dan melaporkan kegiatan } \\
\text { pengelolaan dan pemantauan lingkungan } \\
\text { sesuai dengan ketentuan dan persyaratan } \\
\text { AMDAL }\end{array}$ \\
\hline $\begin{array}{c}\text { Cukup Baik } \\
(80 \% \leq x<100 \%)\end{array}$ & $\begin{array}{l}\text { Melaksanakan dan melaporkan kegiatan } \\
\text { pengelolaan dan pemantauan lingkungan, } \\
\text { akan tetapi beberapa upaya belum mencapai } \\
\text { hasil yang sesuai dengan ketentuan dan } \\
\text { persyaratan dalam AMDAL }\end{array}$ \\
\hline $\begin{array}{c}\text { Kurang Baik } \\
(50 \% \leq \mathrm{x}<80 \%)\end{array}$ & $\begin{array}{l}\text { Melaksanakan dan melaporkan kegiatan } \\
\text { pengelolaan dan pemantauan lingkungan, } \\
\text { akan tetapi baru sebagian mencapai hasil } \\
\text { yang sesuai dengan ketentuan dan } \\
\text { persyaratan dalam AMDAL }\end{array}$ \\
\hline $\begin{array}{l}\text { Sangat Kurang } \\
(<50 \%)\end{array}$ & $\begin{array}{l}\text { Melaksanakan dan melaporkan kegiatan } \\
\text { pengelolaan dan pemantauan lingkungan, } \\
\text { akan tetapi baru sebagian kecil mencapai } \\
\text { hasil yang sesuai dengan ketentuan dan } \\
\text { persyaratan dalam AMDAL }\end{array}$ \\
\hline
\end{tabular}

b. Evaluasi dampak lingkungan sesuai dengan ketentuan dalam izin dan dokumen pengelolaan dengan penyajian data hasil pengukuran dampak lingkungan dikumpulkan dan diolah dengan cara :

- Hasil pengukuran/pemantauan dibandingkan dengan ketentuan ilmiah, peraturan perundang-undangan, perizinan atau standar lainnya.

- Untuk dampak yang telah memiliki baku mutu lingkungan sesuai peraturan perundangundangan seperti udara, air, dilakukan penilaian tingkat kritis dan penaatan. Perhitungan tingkat kekritisan dampak dilakukan menggunakan data hasil pemantauan dari waktu ke waktu maupun data dari pemantauan sesaat. Adapun tahapan penilaian adalah sebagai berikut : Tahap pertama melakukan penilaian menggunakan baku mutu lingkungan sesuai peraturan perundang-undangan berlaku yakni pengendalian dan pencemaran udara, pengelolaan kualitas dan pengendalian pencemaran air. Tahap selanjutnya penilaian tingkat kritis suatu dampak dilakukan dengan melakukan perhitungan dengan rumus : Tingkat kritis $=\frac{\mathrm{P}}{\mathrm{BML}} \times 100 \%$, keterangan : $\mathrm{P}$ $=$ nilai pengukuran parameter dampak; BML = baku mutu lingkungan. 
Selanjutnya kategori tingkat kritis dampak lingkungan diklasifikasikan seperti pada tabel 2 berikut.

Tabel 2. Penilaian Tingkat Kritis Dampak

\begin{tabular}{|c|c|}
\hline Nilai Kritis (\%) & Keterangan \\
\hline$<21$ & Sangat Rendah \\
\hline $21-40$ & Rendah \\
\hline $41-60$ & Sedang \\
\hline $61-80$ & Tinggi/Kritis \\
\hline$>81$ & Sangat Tinggi/Kritis \\
\hline
\end{tabular}

- Penilaian status mutu air dan udara ambien

- Penilaian penaatan yakni tingkat kepatuhan dari pemrakarsa kegiatan untuk memenuhi berbagai ketentuan yang terdapat dalam izin atau pelaksanaan dari ketentuan-ketentuan yang terdapat dalam dokumen pengelolaan lingkungan hidup. Skoring penilaian Kepatuhan Terhadap Ketentuan Baku Mutu Lingkungan Sesuai peraturan Perundangundangan

Kategori penilaian tingkat penataan terhadap baku mutu lingkungan dapat dilihat pada tabel 3 berikut.

Tabel 3. Kategori Penilaian Tingkat Penaatan Terhadap Baku Mutu Lingkungan

\begin{tabular}{|c|l|}
\hline Kategori & \multicolumn{1}{|c|}{ Keterangan } \\
\hline Baik & $\begin{array}{l}100 \% \text { data pemantauan memenuhi BML atau } \\
\text { ketentuan teknis lainnya yang dipersyaratkan }\end{array}$ \\
\hline $\begin{array}{c}\text { Cukup } \\
\text { Baik } \\
\text { ketentuan teknis lainnya yang dipersyaratkan }\end{array}$ \\
\hline $\begin{array}{c}\text { Kurang } \\
\text { Baik }\end{array}$ & $\begin{array}{l}50 \leq \mathrm{x}<80 \text { data pemantauan memenuhi BML atau } \\
\text { ketentuan teknis lainnya yang dipersyaratkan }\end{array}$ \\
\hline $\begin{array}{c}\text { Sangat } \\
\text { Kurang }\end{array}$ & $\begin{array}{l}<0 \text { data pemantauan memenuhi BML atau } \\
\text { ketentuan teknis lainnya yang dipersyaratkan }\end{array}$ \\
\hline
\end{tabular}

\section{HASIL DAN PEMBAHASAN}

Dokumen RKL-RPL kegiatan kehutanan telah memperoleh persetujuan kelayakan lingkungan berdasarkan persetujuan dari Komisi Pusat AMDAL Departemen Kehutanan Nomor : 4214/Dj-VI/PA/93 tanggal 18 Desember 1993 dan persetujuan dokumen RKL-RPL Nomor : 197/DJ-VI/AMDAL/1994 tanggal 19 November 1994. Rencana kegiatan IUPHHK-HA dengan luas areal yang dikaji $\pm 81.000 \mathrm{Ha}$.

\section{Kualitas dan kelengkapan dokumen pelaporan}

Dalam Undang-Undang RI Nomor 32 tahun 2009 tentang Perlindungan dan Pengelolaan Lingkungan Hidup dinyatakan keberlangsungan suatu industri dan perusahaan sangat dipengaruhi oleh pelaksanaan RKLRPL sebagai ujung tombak implementasi AMDAL. Agar implementasi AMDAL untuk suatu kegiatan/usaha optimal, diperlukan strategi pemenuhan program pengelolaan lingkungan yang tercantum dalam RKL-RPL. Perusahaan yang diteliti telah dilengkapi dengan dokumen Andal, RKL-RPL yang telah disyahkan dan mendapat rekomendasi dari instansi yang berwenang. Salah satu instrumen pengelolaan hidup adalah RKL-RPL dimana dokumen RKL-RPL merupakan dokumen operasional dalam mengimplementasikan untuk memantau kondisi lingkungan hidup.

Peraturan Pemerintah Nomor 27 Tahun 2012 Pasal 53 menjelaskan Kewajiban Pemegang Izin Lingkungan: (a) menaati persyaratan dan kewajiban yang dimuat dalam izin lingkungan, (b) membuat dan menyampaikan laporan pelaksanaan terhadap persyaratan dan kewajiban dalam izin lingkungan kepada Menteri, gubernur, atau bupati/walikota; dan (c) Menyediakan dana penjamin untuk pemulihan fungsi lingkungan hidup sesuai ketentuan PUU. Laporan disampaikan secara berkala setiap 6 (enam) bulan. Frekuensi pelaporan dilakukan sesuai dengan Surat Keputusan Kelayakan Lingkungan Hidup atau yang tertuang di dalam dokumen Lingkungan.

Untuk mengetahui sejauhmana kualitas dokumen pelaksanaan pengelolaan dan pemantauan lingkungan hidup pada perusahan, maka dilakukan tinjauan ulang (review) terhadap dokumen tersebut dengan merujuk kepada Keputusan Menteri Negara Lingkungan Hidup RI Nomor 45 Tahun 2005 tentang Pedoman Penyusunan Laporan Pelaksanaan Rencana Pengelolaan Lingkungan Hidup (RKL) dan Rencana Pemantauan Lingkungan Hidup (RPL). Penilaian kualitas dan kelengkapan dokumen berdasarkan telaah substansi pelaporan yang telah disampaikan oleh perusahaan.

Pelaporan pelaksanaan pengelolaan dan pemantauan lingkungan sesuai dengan rumusan dalam dokumen RKL-RPL dan telah dilakukan secara rutin disampaikan oleh perusahaan kepada Dinas Lingkungan Provinsi dan Kabupaten. Berdasarkan frekuensi pelaporan, perusahaan telah memenuhi kewajiban dalam laporan menyampaikan secara berkala setiap tiga bulan dan enam bulan. Pelaporan dokumen pelaksanaan pengelolaan dan pemantauan lingkungan hidup yang diterima oleh Dinas Lingkungan Hidup Provinsi dan Kabupaten dapat dijadikan sumber untuk memberikan gambaran ketaatan dan kesadaran perusahaan dalam upaya melestarikan lingkungan hidup. Selain itu pelaporan dokumen ini dapat meningkatkan penaatan perusahaan dalam pengendalian dampak lingkungan, meningkatkan kesadaran perusahaan untuk mentaati peraturan perundang-undangan dibidang lingkungan hidup, serta mendorong perusahaan untuk berbudaya hijau dan bersih secara berkelanjutan.

Sistematika dan substansi dokumen pelaporan berdasarkan yang telah disampaikan sebagai berikut :

a. Pendahuluan memuat identitas perusahan, lokasi usaha dan/atau kegiatan, deskripsi kegiatan.

b. Pelaksanaan dan evaluasi memuat kegiatan pengelolaan lingkungan, kegiatan pemantauan lingkungan dan evaluasi. Pelaksanaan pengelolaan dan pemantauan berdasarkan kawasan lindung dan konservasi lainnya serta areal efektif untuk produktif. Komponen lingkungan yang dikelola dan dipantau adalah komponen fisik-kimia, biologi, sosekbud dan pengelolaan limbah. Tidak 


\section{This work is licensed under a Creative Commons Attribution-ShareAlike 4.0 License}

ada penjelasan mengenai substansi evaluasi pengelolaan dan pemantauan dampak dampak.

c. Kesimpulan menguraikan efektifitas dan kendala dalam pengelolaan lingkungan serta kesesuaian rencana dan hasil pelaksanaan pengelolaan dan pemantauan lingkungan.

Telaahan pelaporan yang telah disampaikan terhadap ketentuan dalam pedoman pelaksanaan pengelolaan dan pemantauan dampak lingkungan terdapat hal-hal yang belum memenuhi. Hal ini terlihat pada empat indikator yang digunakan dalam penilaian yakni kelengkapan dokumen, penyampaian laporan, frekuensi laporan dan substansi dokumen. Meskipun keempat indikator tersebut terpenuhi, namun ada beberapa hal esensial yang belum dipenuhi dari ketentuan yang telah ditetapkan, yakni subtansi pelaporan yang belum dicantumkan atau tidak sesuai adalah bab pendahuluan pada sub bahasan perkembangan lingkungan sekitar dan bab pelaksanaan dan evaluasi pada sub bahasan evaluasi. Perusahaan belum menyampaikan bahasan mengenai evaluasi kecenderungan (trend evaluation), evaluasi tingkat kritis (criticial level evaluation), evaluasi penaatan (compliance evaluation). Kekurangan lainnya untuk implementasi pengelolaan tidak menyertakan data kuantitaif dari aktivitas yang dilakukan, sedangkan pada pemantauan yang disampaikan bukan pada parameter dampak tapi memantau bentuk/tindakan pengelolaan yang dilakukan. Ketidakadaan informasi data kuantitaif ini menimbulkan kesulitan dalam melakukan evaluasi kegiatan yang berujung pada tidak tercantumnya sub bahasan evaluasi atau isi bahasan yang tidak sesuai ketentuan pelaporan. Penilaian tingkat capaian hasil implementasi kegiatan pengelolaan dan pemantauan dampak lingkungan.

Implementasi pengelolaan dan pemantauan dampak lingkungan

Pengelolaan lingkungan mencakup komponen lingkungan yakni kawasan lindung dan kawasan konservasi lainnya, komponen fisik kimia (iklim mikro, tanah, hidrologi), komponen biologi (vegetasi, satwa liar, biota perairan), komponen sosial ekonomi budaya dan komponen pengelolaan limbah. Komponen-komponen tersebut secara berkesinambungan dan menyeluruh. Penerapan konsep HCVF (High Conservation Value Forest) merupakan langkah positif dalam melindungi keanekaragaman hayati, lanskep, dan ekosistem yang bernilai konservasi tinggi yang terdapat di areal dimana pelaksanaannya diintegrasikan dengan pengelolaan kawasan lindung yang telah diatur dalam undang-undang. Berdasarkan dokumen RKL-RPL yang telah disetujui tercantum bahwa kewajiban pengelolaan dan pemantauan dampak sebanyak 12 jenis dampak terdiri dari 3 jenis dampak komponen fisik kimia, 3 jenis dampak komponen biologi dan 6 jenis dampak pada komponen sosial.

Pelaksanaan pengelolaan lingkungan dimaksudkan untuk mengembangkan sumberdaya lingkungan secara optimal sekaligus menjaga keseimbangan dan kelestarian lingkungan di sekitar kawasan hutan dan sekitarnya. Berdasarkan analisis terhadap dokumen Laporan Pelaksanaan RKL-RPL terhadap proses kegiatan pengelolaan dan pemantauan lingkungan yang telah dilaksanakan perusahaan kehutanan, maka diperoleh data mengenai proses, kesesuaian dan capaian hasil implementasi yang dibuat perusahaan. Tingkat capaian perusahaan terhadap jenis dampak wajib dikelola dan dipantau sebesar $100 \%$ tergolong "baik", yakni dampak wajib 12 dampak dan telah direalisasikan pengelolaan dan pemantauan sebanyak 12 dampak. Hal ini menunjukkan manajemen telah memenuhi kewajiban untuk melakukan pengelolaan dampak lingkungan sesuai dengan yang tercantum dalam dokumen RKL. Hal yang diperhatikan adalah adanya sebagian besar bentuk implementasi pengelolaan yang dilakukan yang belum memberikan infomasi data kuantitatif dalam laporan seperti luasan areal penanaman dan pemeliharaan, besaran bantuan program CSR, jumlah tenaga kerja lokal, jumlah unit usaha ekonomi perseorangan atau badan yang terlibat, dll. Hal ini akan menyulitkan dalam melakukan evaluasi keberhasilan kegiatan pengelolaan yang telah dilakukan. Tidak adanya data kuantitatif menunjukkan antara bagian dalam organisasi belum terkoordinasi dengan baik, dimana data tersebut tidak atau belum tersampaikan ke bagian lingkungan.

Hasil rekapitulasi tingkat capaian hasil implementasi kegiatan pengelolaan dampak lingkungan pada perusahaan yang diteliti tercantum pada tabel 4 berikut.

Tabel 4. Tingkat Capaian Hasil Implementasi Kegiatan Pengelolaan Dampak Lingkungan

\begin{tabular}{|c|c|c|c|}
\hline \multirow{2}{*}{$\begin{array}{c}\text { Tingkatan } \\
\text { Capaian } \\
\text { Implementasi }\end{array}$} & \multicolumn{3}{|c|}{$\begin{array}{c}\text { Komponen Lingkungan } \\
\text { Terkena Dampak }\end{array}$} \\
\cline { 2 - 4 } & Fisik Kimia & Biologi & Sosial \\
\hline Nilai (\%) & 74,24 & 100 & 100 \\
\hline Rata-Rata & \multicolumn{3}{|c|}{91,41} \\
\hline Kategori & \multicolumn{3}{|c|}{ Cukup Baik } \\
\hline
\end{tabular}

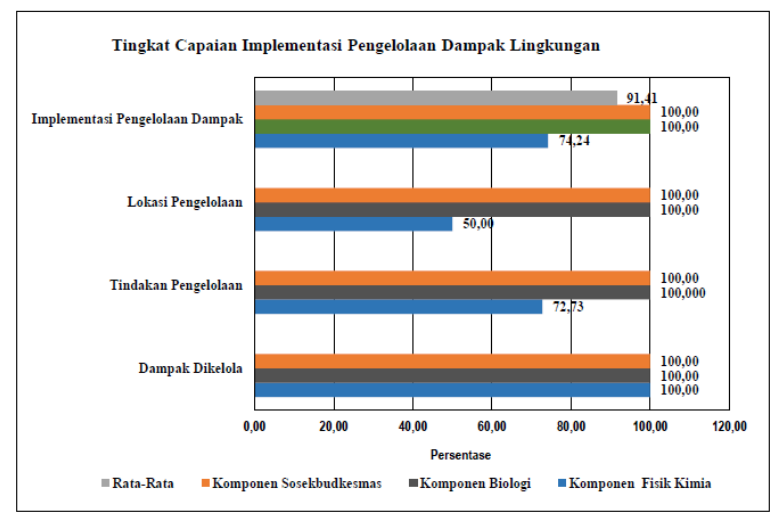

Gambar 1. Tingkat Capaian Implementasi Pengelolaan Dampak Lingkungan

Hasil rekapitulasi tingkat capaian hasil implementasi kegiatan pengelolaan dampak lingkungan 
ditinjau dari komponen lingkungan yang terkena dampak yakni komponen fisik kimia, biologi dan sosial. Tingkat capaian untuk komponen fisik kimia kategori "kurang baik" (74,24\%), komponen biologi dan sosial termasuk kategori "baik" (100\%). Secara umum dapat dikatakan tingkat capaian hasil implementasi kegiatan pengelolaan dampak lingkungan yang telah dilakukan sebesar 91,41\% tergolong dalam kategori "cukup baik" sama artinya melaksanakan dan melaporkan kegiatan pengelolaan lingkungan, akan tetapi beberapa upaya belum mencapai hasil yang sesuai dengan ketentuan dan persyaratan dalam AMDAL.

Implementasi pengelolaan lingkungan sudah berjalan dengan baik sesuai dengan yang direncanakan, hanya perlu perhatian dan perbaikan pada komponen fisik kimia yang belum optimal dilakukan pengelolaan. Hasil ini menunjukkan bahwa masih terdapat kekurangan pada perusahaan dalam menggunakan dokumen RKL sebagai pedoman dalam melaksanakan setiap kegiatan pengelolaan dampak lingkungan. Padahal menurut Permen LHK (2012) rencana pengelolaan lingkungan merupakan upaya penanganan dampak lingkungan yang ditimbulkan dari rencana usaha dan/atau kegiatan. Selanjutnya dijelaskan tujuan utama rencana pengelolaan lingkungan adalah untuk mencegah, mengendalikan dan menanggulangi dampak penting lingkungan hidup dan dampak lingkungan hidup lainnya yang bersifat negatif dan meningkatkan dampak positif yang timbul sebagai akibat dari suatu rencana usaha dan/atau kegiatan. Dengan adanya pedoman ini seharusnya dalam setiap proses atau kegiatan pengelolaan dampak lingkungan oleh perusahaan dapat dilakukan dengan baik, lebih terarah, efektif dan efisien.

Monitoring secara terpadu yang mencakup seluruh aspek lingkungan baik vegetasi, satwa, tanah, air maupun sosial ekonomi dan budaya masyarakat setempat. Berdasarkan dokumen RPL dan laporan pelaksanaan pemantauan lingkungan, maka rencana dan implementasi pemantauan lingkungan pada tahap operasional yang dilakukan menunjukkan bahwa seluruhnya 12 dampak $(100,00 \%)$ telah dilakukan pemantauan sesuai dengan tercantum dalam dokumen RKL.

Hasil rekapitulasi tingkat capaian hasil implementasi kegiatan pemantauan dampak lingkungan pada perusahaan yang diteliti tercantum pada tabel 5 berikut.

Tabel 5. Tingkat Capaian Hasil Implementasi Kegiatan Pemantauan Dampak Lingkungan

\begin{tabular}{|c|c|c|c|}
\hline \multirow{2}{*}{$\begin{array}{c}\text { Tingkatan } \\
\text { Capaian } \\
\text { Implementas } \\
\text { i }\end{array}$} & \multicolumn{3}{|c|}{$\begin{array}{c}\text { Komponen Lingkungan } \\
\text { Terkena Dampak }\end{array}$} \\
\cline { 2 - 4 } & Fisik Kimia & Biologi & Sosial \\
\hline Nilai (\%) & 91,07 & 83,33 & 94,44 \\
\hline Rata-Rata & \multicolumn{3}{|c|}{89,61} \\
\hline Kategori & \multicolumn{3}{|c|}{ Cukup Baik } \\
\hline
\end{tabular}

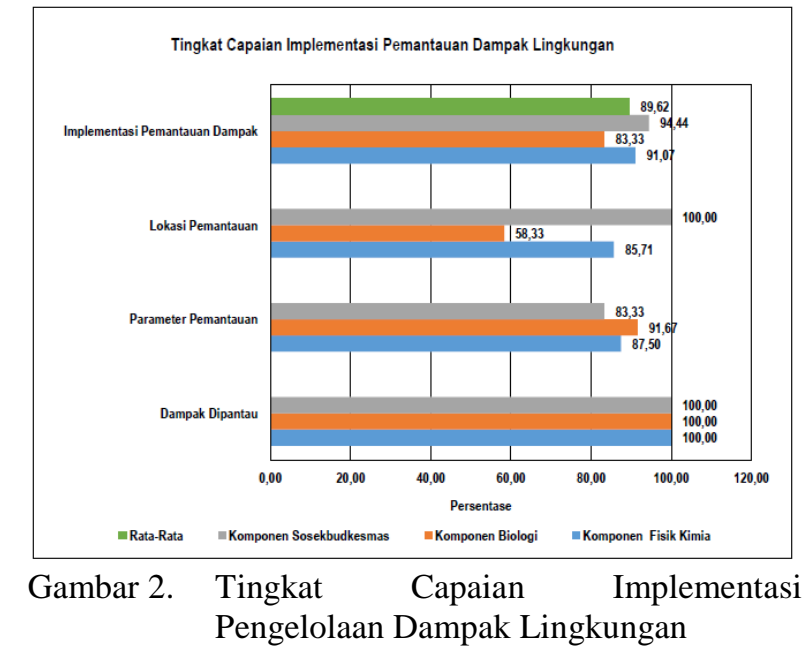

Tingkat capaian implementasi kegiatan pemantauan lingkungan pada komponen fisik kimia termasuk kategori "Cukup Baik" (91,07\%); komponen biologi kategori "Cukup Baik" pada bidang kehutanan $(83,33 \%)$, komponen sosial termasuk pada kategori "Cukup Baik" (94,44\%) Secara umum dapat dikatakan tingkat capaian hasil implementasi kegiatan pemantauan dampak lingkungan yang telah dilakukan sebesar 89,62\% tergolong dalam kategori "cukup baik" sama artinya melaksanakan dan melaporkan kegiatan pemantauan lingkungan, akan tetapi beberapa upaya belum mencapai hasil yang sesuai dengan ketentuan dan persyaratan dalam AMDAL.

Seperti hal kegiatan pengelolaan, tingkat capaian hasil pemantauan menunjukkan perusahaan sangat kurang dalam menggunakan dokumen RPL sebagai pedoman dalam melaksanakan setiap kegiatan pemantauan dampak lingkungan. Padahal rencana pemantauan lingkungan merupakan upaya pemantauan komponen lingkungan hidup yang terkena dampak akibat rencana usaha dan/atau kegiatan, yang pelaksanaannya berlangsung secara terus-menerus, sistematis dan terencana. Selanjutnya pemantauan lingkungan hidup digunakan untuk memahami fenomena-fenomena dan perilaku dampak yang timbul akibat usaha dan/atau kegiatan sebagai indicator untuk mengevaluasi penaatan (compliance), kecenderungan (trendline) dan tingkat kritis (critical level) dari suatu pengelolaan lingkungan hidup. Dengan melakukan pemantauan sekaligus akan dapat dinilai/diuji efektivitas kegiatan pengelolaan lingkungan hidup yang dijalankan.

Manajemen perusahaan telah mengembangkan sistem monitoring dan evaluasi terhadap dampak yang ditimbulkan dari kegiatan operasionalnya. Upaya pemantauan dampak dilaksanakan melalui kegiatan Hasil pemantauan pada komponen sosekbud belum memberikan infomasi data kuantitatif dalam laporan seperti besaran bantuan, jumlah unit usaha ekonomi perseorangan atau badan yang terlibat, dll. Tidak adanya data kuantitatif menunjukkan antar bagian dalam organisasi belum terkoordinasi dalam 
penyampaian data dari kegiatan yang dilaksanakan bagian/bidang lain ke bagian/bidang lingkungan. Hasil pelaksanaan pemantauan lingkungan dapat digunakan sebagai bahan evaluasi efektivitas implementasi pengelolaan serta untuk menilai keberhasilan perusahaan dalam melakukan kegiatan pengusahaan hutan yang berwawasan lingkungan. Implementasi pemantauan lingkungan sudah berjalan dengan baik sesuai dengan yang direncanakan, hanya perlu perhatian dan perbaikan pada penyampaian parameter dampak dan data kuantitatif sehingga dapat digunakan sebagai dasar menganalisa pola kecenderungan perubahan dampak.

Beberapa penyebab yang membuat beberapa perusahaan tingkat capaian hasil implementasi kegiatan pengelolaan dan pemantauan dampak lingkungan belum optimal, diantaranya adalah :

a. Koordinasi antar unit perusahaan belum berjalan optimal terkhusus upaya/tindakan pengelolaan dampak lingkungan yang dilaksanakan oleh diluar unit lingkungan.

b. Fokus pengelolaan dan pemantauan dampak lingkungan terkonsentrasi yang dipersyaratkan kebijakan sektoral seperti PHPL dan Proper.

c. Perusahaan kurang memahami tata cara/teknis pembuatan laporan dan isi dari rumusan dokumen RKL-RPL karena minimnya sosialisasi tentang petunjuk teknis sesuai Keputusan Menteri Negara Lingkungan Hidup Nomor: 45 Tahun 2005 terutama substansi yang harus dicantumkan dalam setiap pelaporan pengelolaan dan pemantauan

d. Jadwal pemantauan dan pengukuran parameter lingkungan tidak rutin atau sering terlewat.

e. Kesulitan dalam mendapatkan Laboratorium Pengujian Lingkungan tersertifikasi disebabkan oleh jadwal sampling yang padat.

f. Kurang atau minimnya staff pengelolaan dan pemantauan lingkungan.

g. Perusahaan tidak terlalu memahami jika hasil pengujian melebihi/tidak sesuai dengan standar baku mutu yang ditetapkan.

h. Pergantian staf bagian lingkungan mempengaruhi konsistensi dan kesinambungan laporan.

i. Kurangnya umpan balik atau koreksi terhadap laporan pelaksanaan pengelolaan dan pemantauan dari Instansi Pemerintah baik instansi teknis kehutanan maupun instansi lingkungan hidup

j. Komitmen dari perusahaan relatif kurang di dalam kegiatan operasional perusahaan untuk melaksanakan program pengelolaan dan pemantauan lingkungan hidup

Beberapa penyebab Instansi Pemerintah baik instansi teknis kehutanan, maupun instansi lingkungan hidup belum dapat menilai kinerja pengelolaan lingkungan hidup berdasarkan laporan pelaksanaan pengelolaan dan pemantauan lingkungan hidup, diantaranya adalah : a. Kurang atau minimnya staff khusus yang menilai pelaksanaan pengelolaan dan pemantauan lingkungan

b. Kemampuan pengetahuan staff yang memiliki kompetensi sangat terbatas.

c. Pergantian staf mempengaruhi konsistensi dan kesinambungan pengawasan.

\section{Evaluasi Dampak Lingkungan}

Pembahasan evaluasi dampak lingkungan dilakukan pada beberapa dampak yang telah dipantau dengan menyesuaikan ketersediaan data kuantitatif dari implementasi pemantauan dampak yang telah dilakukan oleh perusahaan dan disampaikan dalam laporan triwulan atau semester. Penilaian evaluasi dampak lingkungan dilakukan dengan membandingkan dengan ketentuan ilmiah, peraturan perundanundangan, perizinan atau standar lainnya. Selanjutnya dampak lingkungan yang telah memiliki baku mutu lingkungan sesuai dengan peraturan perundangundangan dilakukan penilaian tingkat kritis dan penaatan. Penilaian tingkat kritis merupakan penilaian terhadap tingkat potensi resiko, sedangkan penaatan merupakan tingkat kepatuhan dari kegiatan perusahaan untuk memenuhi berbagai ketentuan yang terdapat dalam izin atau pelaksanaan dari ketentuan-ketentuan yang terdapat dalam dokumen pengelolaan lingkungan hidup (RKL-RPL).

\section{Komponen fisik kimia}

Erosi tanah merupakan peristiwa pengikisan lapisan tanah (umumnya yang terletak di permukaan lahan) oleh air hujan melalui dua proses berurutan yang terpisah, yaitu pemecahan tanah yang diikuti oleh pengangkutan bahan-bahan tanah terpecah dan pengendapannya (Purwowidodo 1999). Hasil pemantauan laju erosi dan tingkat kritis dampak pada wilayah kerja kehutanan menunjukkan laju erosi kegiatan kehutanan sebesar 92,91 Ton/Ha/Tahun termasuk dalam kategori Kelas III atau TBE sedang. Dari hasil tersebut teridentifikasi sebagai wilayah yang memiliki tingkat bahaya erosi perlu dilakukan upaya pencegahan erosi berupa tindakan konservasi tanah dan perbaikan pengolahan lahan agar tingkat bahaya erosi tidak menjadi lebih berat. Faktor-faktor yang mempengaruhi besarnya erosi di areal hutan akibat kegiatan pemanenan hutan antara lain kurangnya penerapan teknik pemanenan hutan yang benar dan kurangnya tindakan konservasi tanah, sedangkan di areal penambangan akibat penutupan covercrop dan vegetasi masih belum merata dan kondisi kemiringan lahannya. Alternatif strategi penanggulangan erosi tanah dengan menerapkan upaya pengelolaan dampak lingkungan secara konsisten antara lain pembuatan cross drain, penanaman cover crop di areal terbuka yang telah ditinggalkan, penerapan teknik pemanenan hutan dan penanaman yang benar.

Hasil pengukuran lapangan terhadap beberapa parameter fisika, kimia anorganik, mikrobiologi di perairan sungai sekitar areal kerja perusahaan 


\section{This work is licensed under a Creative Commons Attribution-ShareAlike 4.0 License}

menunjukan kualitas air, secara umum 93,33\% masih memenuhi baku mutu lingkungan air, sedangkan $6,67 \%$ telah melampaui baku mutu air pada sumber air kelas II berdasarkan Perda Kaltim Nomor : 02 Tahun 2011. Hasil ini menunjukkan bahwa kegiatan kehutanan di wilayah kerja perusahaan memenuhi kepatuhan atau penaatan terhadap ketentuan dalam pengendalian pencemaran air berdasarkan Perda Kaltim Nomor : 02 Tahun 2011 termasuk dalam kategori "cukup baik" (93,33\%).

Kondisi kualitas air permukaan pada masingmasing sungai sebagai berikut :

a. Sungai Seleq : dari 15 parameter menunjukkan 13 parameter $(86,67 \%)$ memenuhi baku mutu air dan 2 parameter $(13,33 \%)$ melampaui baku mutu air yakni parameter nitrit dan timbal.

b. Sungai Melguan : dari 15 parameter menunjukkan 13 parameter $(86,67 \%)$ memenuhi baku mutu air dan 2 parameter $(13,33 \%)$ melampaui baku mutu air yakni parameter nitrit dan $\mathrm{CaCO}_{3}$.

c. Sungai Hess, Jamtek, Wahau dan Sekung : dari 15 parameter menunjukkan 14 parameter $(93,33 \%)$ memenuhi baku mutu air dan 1 parameter $(6,67 \%)$ melampaui baku mutu air yakni parameter nitrit.

d. Sungai Belkin : dari 15 parameter menunjukkan 14 parameter $(93,33 \%)$ memenuhi baku mutu air dan 1 parameter $(6,67 \%)$ melampaui baku mutu air yakni parameter DO.

e. Sungai Biha dan Ajan : 15 parameter menunjukkan masih memenuhi baku mutu air.

Jika dihubungkan dengan tingkat kekritisan dampak dari parameter air pada 9 sungai, hasilnya menunjukkan parameter tingkat kritis dampak kategori "sangat tinggi" (10,37\%), "tinggi" (2,22\%), "sedang" $(18,525)$, "rendah" $(13,33 \%)$ dan "sangat rendah" $(55,56 \%)$. Secara umum perairan sungai sekitar kegiatan perusahaan kehutanan pada tingkat kritis "rendah" (68,89\%).

Dari hasil analisis menunjukkan kualitas air sungai telah mengalami perubahan sebagai akibat terjadinya pencemaran air. Hal ini diindikasikan dengan menurunnya nilai kualitas air sungai sampai tingkat tertentu yang menyebabkan air tidak dapat berfungsi sesuai peruntukkannya kelas II. Dari 9 sungai yang dipantau terdapat 4 parameter yang telah melampaui baku mutu air tersebut yakni :

a. Parameter timbal pada 1 sungai telah mencapai tingkat kritis adalah Sungai Seleq dengan tingkat kritis dampak 186,67\%. Kandungan timbal yang tinggi dipengaruhi oleh aktivitas manusia karena di lokasi sekitar sungai terdapat pemukiman penduduk yang memanfaatkan dan membuang limbah domestik ke sungai serta lokasi yang berdekatan aktivitas kehutanan, pertanian masyarakat dan perkebunan. Menurut Darmono (1995), masuknya buangan yang mengandung logam berat yang berasal dari limbah domestik dan pertanian mempengaruhi konsentrasi logam berat di perairan. Salah satu faktor yang cukup besar dalam menyumbangkan logam $\mathrm{Pb}$ ke dalam perairan adalah cairan limbah rumah tangga dan aliran air (Connel dan Miller, 1995).

b. Parameter DO pada 1 sungai telah mencapai tingkat kritis adalah Sungai Belkin dengan tingkat kritis dampak $102,83 \%$. Rendahnya parameter konsentrasi parameter dissolved oxygen (DO) hingga di bawah batas minimum kemungkinan disebabkan kurangnya keberadaan biota vegetasi sungai. Sumber utama oksigen dalam suatu perairan berasal hasil fotosintesis organisme yang hidup dalam perairan tersebut, selain dari proses difusi dari udara bebas. Menurut Salmin (2005), kandungan DO pada suatu perairan sangat berhubungan dengan tingkat pencemaran, jenis limbah dan banyaknya bahan organik di suatu perairan.

c. Parameter kesadahan sebagai $\mathrm{CaCO}_{3}$ pada 1 sungai telah mencapai tingkat kritis adalah Sungai Melguan dengan tingkat kritis dampak 125,33\%. Peningkatan parameter kesadahan sebagai $\mathrm{CaCO}_{3}$ diduga adanya kandungan $\mathrm{CaCO}$ dalam batubatuan kapur yang secara alami terdapat di air sungai yang berdekatan dengan kawasan Karst. Astuti dkk (2015) mengemukakan kesadahan semakin meningkat jika berdekatan dengan kawasan bukit. Kapur. Menurut Abidjulu, 2008, kapur $(\mathrm{CaCO})$ dapat larut dalam air akibat adanya $\mathrm{CO}$ yang membentuk mineral-mineral karbonat yang larut dalam air. Peningkatan tingkat kesadahan air diduga juga dapat disebabkan oleh meningkatnyanya ion-ion $\mathrm{Ca}^{2+}$ dan $\mathrm{Mg}^{3+}$ dalam air. Peningkatan ion-ion $\mathrm{Ca}^{2+}$ dan $\mathrm{Mg}^{3+}$ dalam air diduga terjadi akibat perubahan ion-ion tersebut menjadi padatan yang tidak larut dalam air dan mengendap di dasar sungai sebagai padatan $\mathrm{CaCO}_{3}$ dan $\mathrm{MgCO}_{3}$. Masuknya $\mathrm{Ca}(\mathrm{OH})_{2}$ ke perairan sungai tersebut dapat terjadi secara alami dari limbah yang berasal dari aktivitas domestik (Ruliasih, 2011)

d. Parameter nitrit pada 6 sungai telah mencapai tingkat kritis adalah Sungai Seleq, Melguan, Hess, Jamtek, Wahau dan Sekung dengan tingkat kritis dampak berkisar antara 250-558,33\%. Kadar parameter nitrit dalam jumlah yang sangat sedikit diperairan alami, kadarnya lebih kecil dari pada nitrat karena bersifat tidak stabil. Konsentrasi ini dapat meningkat berkaitan erat dengan masuknya bahan organik yang mudah urai (baik yang mengandung unsur nitrogen maupun nitrat). Menurut Jualish, dkk (2017), kandungan senyawa nitrit yang tinggi di perairan disebabkan oleh aktifitas yang tinggi dari bakteri pengurai akibat pembuangan limbah rumah tangga, pertanian. Sampah yang mengandung nutrien dapat terurai akibat aktifitas mikroba di perairan. Nitrogen organik mula-mula diurai menjadi ammonia, selanjutnya dioksidasikan menjadi nitrit. Pencemaran oleh pupuk nitrogen, sampah organik 


\section{This work is licensed under a Creative Commons Attribution-ShareAlike 4.0 License}

hewan maupun manusia, dapat meningkatkan kadar nitrit di dalam air (Ramadhan dkk, 2018). Selanjutnya dinyatakan nilai kadar nitrit yang tinggi saat laju fotosintesis tinggi dan kadar nitrogen rendah. Sebaliknya, pada kadar nitrit rendah, sementara kondisi lingkungannya optimal bagi pertumbuhan dan pasokan nutrien lebih tinggi.

Hasil penentuan status mutu air dengan perhitungan metoda indeks pencemaran disajikan pada tabel 6 berikut.

Tabel 6. Hasil Perhitungan Status Mutu Air dengan Metoda Indeks Pencemaran

\begin{tabular}{|c|c|c|}
\hline Sampling Sungai & $\begin{array}{c}\text { Nilai Indeks } \\
\text { Pencemaran }\end{array}$ & Status Mutu Air \\
\hline Sungai Seleq & 2,32 & Cemar Ringan \\
\hline Sungai Melguan & 3,39 & Cemar Ringan \\
\hline Sungai Hess & 2,11 & Cemar Ringan \\
\hline Sungai Belkin & 0,84 & $\begin{array}{c}\text { Memenuhi baku mutu } \\
\text { (kondisi baik) }\end{array}$ \\
\hline Sungai Jamtek & 2,70 & Cemar Ringan \\
\hline Sungai Wahau & 2,15 & Cemar Ringan \\
\hline Sungai Sekung & 3,22 & Cemar Ringan \\
\hline Sungai Biha & 0,29 & $\begin{array}{c}\text { Memenuhi baku mutu } \\
\text { (kondisi baik) }\end{array}$ \\
\hline Sungai Ajan & 0,38 & $\begin{array}{c}\text { Memenuhi baku mutu } \\
\text { (kondisi baik) }\end{array}$ \\
\hline
\end{tabular}

Hasil analisis Indeks Pencemaran (IP), 66,67\% perairan sungai telah tercemar "ringan" (IP 2,11-3,23) dan 33,33\% masih kondisi "baik" (IP 0,29-0,84). Hasil ini mengindikasikan bahwa kondisi air sungai mengalami penurunan kualitas atau terdapat beberapa parameter yang telah melampaui baku mutu kelas II.

\section{Komponen biologi}

Hasil pemantauan di wilayah kerja perusahaan terdapat 79 jenis dengan 10 jenis diantaranya termasuk dalam indeks nilai penting >9,938. Berdasarkan Suripto (2000), keberadaan pohon di wilayah kerja setelah operasional tergolong sangat baik terdapat lebih dari 30 jenis flora. Keanekaragaman jenis sebesar 3,488 berdasarkan berdasarkan kriteria nilai indeks keanekaragaman Shannon-Wiener termasuk kriteria tinggi yang berarti keanekaragaman tinggi, stabilitas ekosistem mantap dan produktivitas tinggi.

Hasil pemantauan fauna di areal kerja menunjukkan keanekaragaman jenis satwa ditemukan sebanyak 17 jenis satwa dilindungi mengalami peningkatan keanekaragaman jenis satwaliar sebesar $70 \%$. Keanekaragaman jenis satwaliar sebesar 1,22 berdasarkan berdasarkan kriteria nilai indeks keanekaragaman Shannon-Wiener termasuk kriteria sedang yang berarti yang berarti keanekaragaman sedang, produktivitas cukup, kondisi ekosistem cukup seimbang dan tekanan ekologis sedang.

Komunitas plankton yang menghuni suatu ekosistem terdiri dari beranekaragam jenis dan masingmasing spesies mempunyai jumlah individu tertentu, dengan demikian ada tiga unsur pokok dari struktur komunitas yaitu jumlah macam jenis, jumlah individu dalam masing-masing jenis dan total individu dalam komunitas. Hubungan antar ketiga hal tersebut menunjukkan nilai keanekaragaman jenis plankton dalam komunitas tersebut. Hasil pemantauan biota perairan di sungai sekitar kawasan hutan menunjukkan nilai indeks keanekaragaman (H') plankton kisaran 1,85-2,33 dan benthos pada nilai 0 (nol). Berdasarkan indeks keanekaragaman Shannon-Wiener untuk plankton termasuk kriteria stabilitas komunitas biota sedang atau kualitas air tercemar sedang, sebaliknya untuk bentos termasuk kriteria stabilitas komunitas biota rendah atau kualitas air tercemar berat. Hasil ini menunjukkan untuk bentos mengalami penurunan dimana sebelum operasional tahun 1993 di beberapa sungai masih ditemukan bentos dan setelah operasional hingga tahun 2017 tidak ditemukan bentos.

\section{Komponen Sosial}

Kesempatan kerja untuk rekruitmen tenaga kerja lokal tahun 1993 sebesar 69,46\%. Berdasarkan hasil pemantauan rekruitmen tenaga kerja lokal di areal tiga tahun terakhir sebesar $90 \%$ atau meningkat $29,57 \%$. Rekruitmen tenaga kerja lokal kegiatan kehutanan secara umum mengalami peningkatan atau melampaui dari rencana awal berdasarkan Andal perusahan. Ini menunjukan komitmen perusahaan dalam memenuhi kepatuhan dalam penaatan melibatkan tenaga kerja lokal

\section{KESIMPULAN}

Kualitas pelaporan belum sepenuhnya memenuhi Pedoman Penyusunan Laporan (Keputusan Menteri Negara Lingkungan Hidup Nomor 45 Tahun 2005) terutama format laporan dan subtansi pelaporan.

Realisasi jenis dampak yang wajib dikelola dan dipantau kategori "baik". Tingkat capaian implementasi kegiatan pengelolaan dan pemantauan dampak lingkungan pada kategori "cukup baik"

Implementasi pengelolaan dan pemantauan lingkungan belum optimal disebabkan oleh permasalahan koordinasi dan komitmen perusahaan, fokus kebijakan sektoral (PHPL dan Proper), jadwal dan kapasitas laboratorium, kapasitas pengetahuan dan kompetensi staf serta tidak ada umpan balik/koreksi. Penilaian pelaksanaan RKL-RPL oleh Instansi Lingkungan Hidup belum optimal disebabkan oleh permasalahan jumlah, kapasitas pengetahuan dan kompetensi staff.

Evaluasi terhadap beberapa dampak hasil pemantauan masih memenuhi ketentuan/standar ilmiah. laju erosi sebesar 92,91 Ton/Ha/Tahun kategori "Kelas III" atau "TBE sedang". Kualitas air sungai sebesar $93,33 \%$ kategori "memenuhi BML" dan 6,67\% kategori "telah melampaui BML" pada sumber air kelas II berdasarkan Perda Kaltim Nomor : 02 Tahun 2011. Parameter air pada tingkat kritis "rendah" 


\section{https://doi.org/10.51967/tanesa.v22i2.884 (C) 2021 Politeknik Pertanian Negeri Samarinda}

\section{This work is licensed under a Creative Commons Attribution-ShareAlike 4.0 License}

(68,89\%). Indeks Pencemaran (IP) 66,67\% tercemar "ringan" (IP 2,11-3,23) dan 33,33\% kondisi "baik" (IP 0,29-0,84). Parameter air sungai yang tidak memenuhi BML meliputi timbal, $\mathrm{DO}, \mathrm{CaCO}_{3}$, nitrit. Indeks keanekaragaman Shannon-Wiener vegetasi termasuk kriteria "tinggi". Indeks keanekaragaman ShannonWiener fauna termasuk kriteria "sedang". Indeks keanekaragaman Shannon-Wiener untuk plankton termasuk kriteria stabilitas komunitas biota sedang atau kualitas air tercemar sedang, sebaliknya untuk bentos termasuk kriteria stabilitas komunitas biota rendah atau kualitas air tercemar berat. Rekruitmen tenaga kerja lokal sebesar $90 \%$ atau meningkat $29,57 \%$ dari sebelum operasional.

\section{DAFTAR PUSTAKA}

Abidjulu J., 2008. Analisis Kualitas Air Sungai Tanoyan Di Kota Kotamobagu Provinsi Sulawesi Utara. Chem. Prog. Vol. 1, No. 2. November 2008

Astuti, D.W.,Rahayu, M., Rahayu, D.S. 2015. Penetapan Kesadahan Total (Caco3) Air Sumur Di Dusun Cekelan Kemusu Boyolali Dengan Metode Kompleksometri. KESMAS, Vol.9, No.2, September 2015, pp. $119 \sim 124$ ISSN: $1978-0575$

Connel, D.W. dan Miller, G.J. 1995, Kimia dan Ekotoksikologi Pencemaran, UI-Press, Jakarta

Darmono, 1995. Logam Dalam Sistem Biologi Makhluk Hidup. Universitas Indonesia, Jakarta

Forest Watch Indonesia, UKaid, The Asia Foundation. 2017. Excecutif Summary Silang Sengkarut Pengelolaan Hutan dan Lahan di Indonesia. Studi Kasus 8 Provinsi di Indonesia (Aceh, Kalimantan Barat, Kalimantan Timur, Kalimantan Utara, Riau, Sulawesi Tengah, Sulawesi Barat, Sulawesi Selatan). http://fwi.or.id/wpcontent/uploads/2017/12/ex ecutivesummary8des17_final.pdf. Diunduh $28 / 06 / 2020$

Dawes et al., (1974)

Departemen Kehutanan. 1998. Pedoman Penyusunan Rencana Teknik Rehabilitasi Teknik Lapangan dan Konservasi Tanah Daerah Aliran Sungai. Departemen Kehutanan. Jakarta

Dewan Daerah Perubahan Iklim Propinsi Kalimantan Timur. 2010. Strategi Pembangunan Kalimantan Timur yang Berkelanjutan dan Ramah Lingkungan. Kalimantan Timur

Juliasih, N.L.G.R, Hidayat, D., Ersa, M.P.,Rinawati. 2017. Penentuan Kadar Nitrit dan Nitrat pada Perairan Teluk Lampung Sebagai Indikator Kualitas Lingkungan Perairan
Ramadhan, M., Tarigan, S.D., Suharnoto, Y., Arifin, H.S. 2018. Pemetaan Status Kualitas Sumberdaya Air Permukaan di Kota Bogor dan Upaya Pengelolaannya Menuju Kota Sensitif Air

Ruliasih. 2011. Penghilangan Kesadahan dalam Air Minum. http://www.kelair.bppt.go.id/publikasi/BukuAirMinum/BAB9SADAH/pdf

Salmin. 2005. Oksigen terlarut (DO) dan kebutuhan oksigen biologi (BOD) sebagai salah satu indikator untuk menentukan kualitas perairan. Oseana, 30(3), 21-26

2011. Peraturan Daerah Provinsi Kalimantan Timur Nomor 02 Tahun 2011 Tentang Pengelolaan Kualitas Air Dan Pengendalian Pencemaran Air 